\title{
Erratum to: An RFID-based traceability system
}

\section{A case study of rice supply chain}

\author{
Worapot Jakkhupan - Somjit Arch-int • Yuefeng Li
}

Published online: 17 December 2014

(C) Springer Science+Business Media New York 2014

\section{Erratum to: Telecommun Syst}

\section{DOI 10.1007/s11235-014-9866-7}

The affiliation and the email address of the corresponding author are incorrect in the published version and are now correctly given in this erratum.

The online version of the original article can be found under doi:10.1007/s11235-014-9866-7.

W. Jakkhupan $(\varangle) \cdot S$. Arch-int

Department of Computer Science, Faculty of Science,

Khon Kaen University, Khon Kaen 40002, Thailand

e-mail: jakkhupan@hotmail.com

S. Arch-int

e-mail: somjit@kku.ac.th

Y. Li

School of Electrical Engineering and Computer Science,

Faculty of Science and Engineering, Queensland University

of Technology, Brisbane, QLD 4001, Australia

e-mail: y2.li@qut.edu.au 